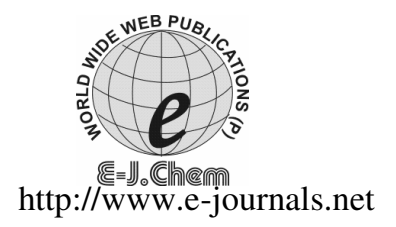

ISSN: 0973-4945; CODEN ECJHAO

E-Journal of Chemistry 2011, 8(2), 635-642

\title{
Synthesis and Antimicrobial Activity of Some New Thioether Derivatives of Quinoxaline
}

\author{
D.C.P.SINGH ${ }^{\S *}$, S.R.HASHIM ${ }^{\S}$ and R.G.SINGHAL \\ ${ }^{\S}$ Department of Pharmaceutical Chemistry \\ College of Pharmacy, Institute of Foreign Trade and Management \\ Moradabad - 244001, India \\ School of Pharmaceutical Sciences \\ Shobhit University, Meerut, India \\ drrgsinghal@rediffmail.com
}

Received 19 September 2010; Accepted 30 October 2010

\begin{abstract}
Chloro-3-methylquinoxaline was selected as nucleus around which the molecular manipulations were carried out to get new compounds expected to possess better anti microbial activity. Various quinoxaline derivatives have been synthesized by replacing the chlorine at C-2 with a thioether linkage, which in turn attached to 2-( $N$-(substituted phenyl)acetamides. The synthesized compounds (5) were tested for their antimicrobial activity. Compounds $\mathbf{5 b}, \mathbf{5 c}, \mathbf{5 d}$ and $\mathbf{5 i}$ were found most active (comparable to the standard antibacterial Ciprofloxacin) amongst them. The structure of the compounds was confirmed on the basis of their spectral data.
\end{abstract}

Keywords: Quinoxalines, 2-Chloro- $N$-(substituted phenyl)acetamides, 2-(2-Methylquinoxalin-3ylthio)- $N$-substituted phenyl)acetamides, Antimicrobial activity.

\section{Introduction}

Compounds containing the quinoxaline nucleus exhibit a broad spectrum of biological activity such as antibacterial ${ }^{1-3}$, antifungal ${ }^{4,5}$, antiviral ${ }^{6}$, anticancer ${ }^{7}$, antituberculosis ${ }^{8}$, antimalarial $^{9}$ and anti-inflammatory ${ }^{10}$. Thioethers have also been reported for their bactericidal, fungicidal, anti-inflammatory anticholestemic, hypolipidemic and neurotropic activities $^{11,12}$, therefore in continuation of our previous work ${ }^{13}$ on 2-chloro-3methylquinoxaline therefore it was thought worthwhile to synthesize thioether derivatives of quinoxaline in search of better antimicrobial agents. We have synthesized twelve new compounds containing thioether linkage. 


\section{Experimental}

The chemical synthesis (Scheme 1) was initiated with the reaction of $o$-phenylenediamine (1) with ethyl pyruvate in $n$-butanol to yield 2-hydroxy-3-methyl quinoxaline (2), which on treatment with $\mathrm{POCl}_{3}$, yielded 2-chloro-3-methylquinoxaline (3). A mixture of the compound (3) and sodium sulphide in DMF was refluxed to yield 3-methylquinoxalin-2thiosodium (4), which on treatment with different $N$-substituted chloroacetamides afforded the one-pot synthesis of 2-(2-methylquinoxalin-3-ylthio)- $N$-substituted phenyl)acetamides (5a-k). 2-Chloro- $N$-substituted acetamides (Table 1) were prepared by treating substituted anilines in glacial acetic acid with chloroacetylchloride, warming on the water bath for half an hour and then precipitating, 2-chloro- $N$-substituted acetamides by addition of saturated aqueous solution of anhydrous sodium acetate. A compound 2-(benzylthio)-3methylquinoxaline (5l) was also prepared. All these compounds (5a-l) are depicted in Table 2.
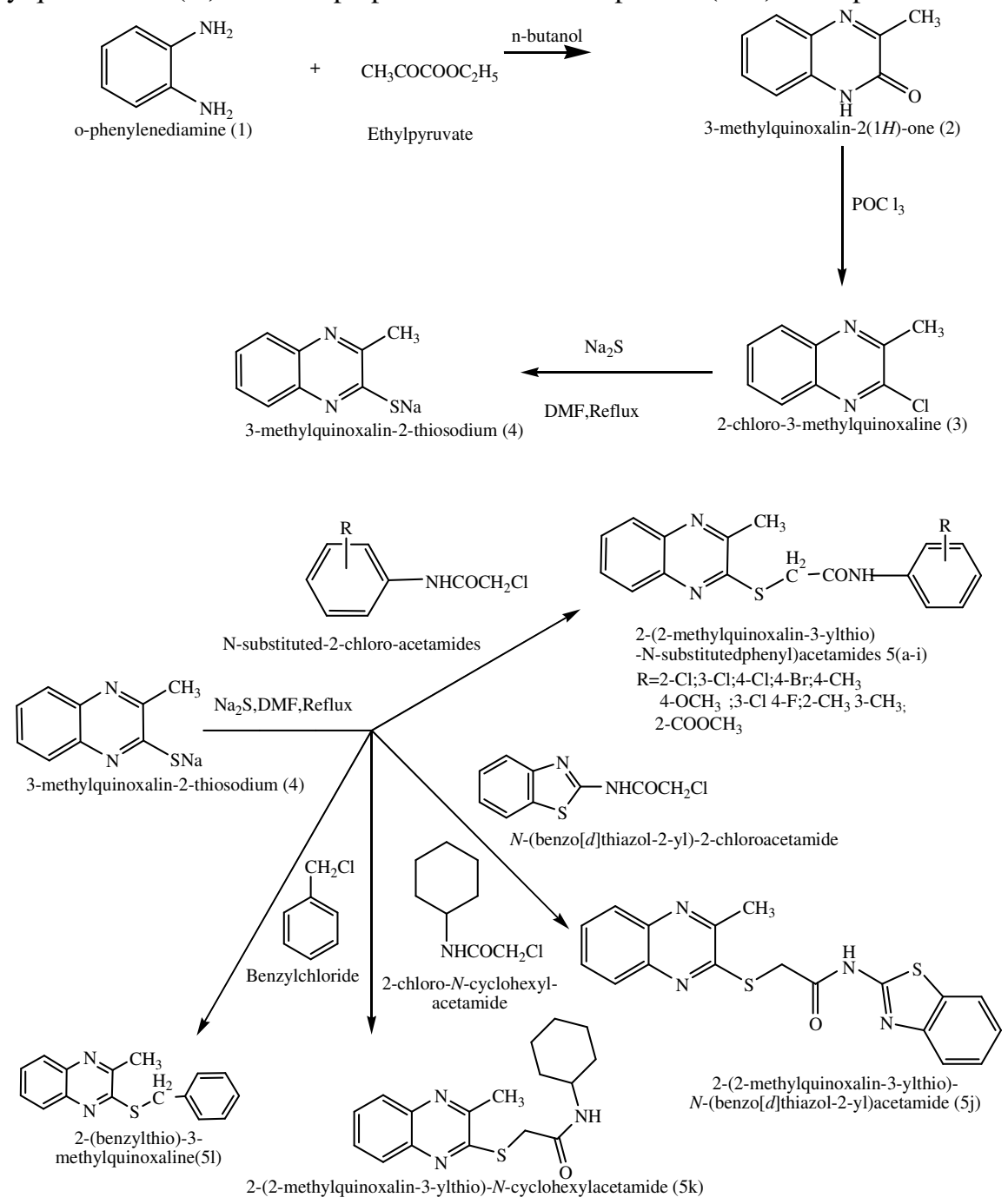

Scheme 1 
Table 1. Physical data of 2-chloro- $N$-(substituted phenyl)acetamides

\begin{tabular}{clcc}
\hline S.No & \multicolumn{1}{c}{ Name } & Melting point ${ }^{\circ} \mathrm{C}$ & $\mathrm{R}_{\mathrm{f}}$ value \\
\hline 1. & 2-Chloro- $N$-(2-chlorophenyl)acetamide & $70-72$ & 0.82 \\
2. & 2-Chloro- $N$-(3-chlorophenyl)acetamide & 78 & 0.80 \\
3. & 2-Chloro- $N$ (4-chlorophenyl)acetamide & $164-166$ & 0.75 \\
4. & 2-Chloro- $N$-(4-bromophenyl)acetamide & $170-172$ & 0.77 \\
5. & 2-Chloro- $N$-( $p$-tolyl)acetamide & $160-162$ & 0.70 \\
6. & 2-Chloro- $N$-(4-methoxyphenyl)acetamide & 104 & 0.86 \\
7. & 2-Chloro- $N$-(3-chloro,4-fluorophenyl)acetamide & $75-77$ & 0.64 \\
8 & 2-Chloro- $N$-(2,3dimethylphenyl)acetamide & $122-124$ & 0.72 \\
9. & methyl 2-(2-chloroacetamido)benzoate & 78 & 0.90 \\
10. & $N$-(Benzo[d]thiazol-2-yl)-2-chloroacetamide. & $141-142$ & 0.68 \\
11. & 2-Chloro- $N$-cyclohexylacetamide & 98 & 0.88 \\
\hline \multicolumn{4}{c}{ Mobile phase for TLC, ethyl acetate: $n$-hexane $(\mathbf{1 : 1})$}
\end{tabular}

Table 2. Physical data of compounds (5a-1) and its structures

\begin{tabular}{|c|c|c|c|c|}
\hline \multicolumn{5}{|c|}{ General structure of the synthesized compounds } \\
\hline Compounds & $\mathrm{X} ; \mathrm{R}$ & Reaction Time & M.P. ${ }^{0} \mathrm{C}$ & $R_{f}$ value \\
\hline 5a. & $\mathrm{C}_{6} \mathrm{H}_{4} ; 2-\mathrm{Cl}$ & $6 \mathrm{H}$ & 138 & 0.90 \\
\hline $5 b$. & $\mathrm{C}_{6} \mathrm{H}_{4} ; 3-\mathrm{Cl}$ & $6 \mathrm{H}$ & 109 & 0.83 \\
\hline $5 c$. & $\mathrm{C}_{6} \mathrm{H}_{4} ; 4-\mathrm{Cl}$ & $6 \mathrm{H}$ & $144-145$ & 0.84 \\
\hline 5d. & $\mathrm{C}_{6} \mathrm{H}_{4} ; 4-\mathrm{Br}$ & $6 \mathrm{H}$ & $166-167$ & 0.80 \\
\hline 5e. & $\mathrm{C}_{6} \mathrm{H}_{4} ; 4-\mathrm{CH}_{3}$ & $5 \mathrm{H}$ & 176 & 0.66 \\
\hline $5 f$. & $\mathrm{C}_{6} \mathrm{H}_{4} ; 4-\mathrm{OCH}_{3}$ & $7 \mathrm{H}$ & 160 & 0.79 \\
\hline $5 g$. & $\mathrm{C}_{6} \mathrm{H}_{3} ; 3-\mathrm{Cl}, 4-\mathrm{F}$ & $9 \mathrm{H}$ & $159-160$ & 0.81 \\
\hline 5h. & $\mathrm{C}_{6} \mathrm{H}_{3} ; 2-\mathrm{CH}_{3}, 3-\mathrm{CH}_{3}$ & $6 \mathrm{H}$ & $182-183$ & 0.78 \\
\hline $5 \mathbf{i}$ & $\mathrm{C}_{6} \mathrm{H}_{4} ; 2-\mathrm{COOCH}_{3}$ & $6 \mathrm{H}$ & 130 & 0.86 \\
\hline 5j. & & $6 \mathrm{H}$ & 180 & 0.57 \\
\hline $5 \mathbf{k}$. & $-\quad ; \mathrm{H}$ & $6 \mathrm{H}$ & $168-169$ & 0.60 \\
\hline 51. & $\mathrm{R}-\mathrm{X}-\mathrm{NHCO}=\mathrm{C}_{6} \mathrm{H}_{5}$ & $2 \mathrm{H}$ & $170-171$ & 0.80 \\
\hline
\end{tabular}

Ethanol was used as the recrystallization solvent Mobile phase for TLC, ethyl acetate: n-hexane (1:1)

The melting points were determined in laboratory melting point apparatus using capillary method and are uncorrected. The purity of the compounds was checked by thin layer chromatography using silica gel- $\mathrm{G}$ on micro slide glass plates and spots were detected under iodine vapor. IR spectra were recorded in $\mathrm{KBr}$ disk on a Simadzu FTIR- 8400 spectrophotometer and ${ }^{1} \mathrm{H}$ NMR spectra on JEOL FTNMR Spectrometer $(300 \mathrm{MHz})$ using TMS as an internal standard. All chemical shift values were recorded as $\delta$ (ppm).

Synthesis of 3-methylquinoxalin-2-(1H)-one (2)

$o$-Phenylenediamine $(10.8 \mathrm{~g}, 0.10 \mathrm{M})$ was dissolved in $300 \mathrm{~mL}$ of $n$-butanol with warming. ethyl pyruvate $[11.6 \mathrm{~g}(15 \mathrm{~mL}), 0.10 \mathrm{M}$ ] was dissolved in $100 \mathrm{~mL}$ of $n$-butanol separately and 
it was added to former solution with constant stirring. The solution was set aside for $30 \mathrm{~min}$, and then it was heated for $1 \mathrm{~h}$ on water bath. On cooling, the crystals that separated, were collected by filtration, washed with $n$-hexane and were purified by recrystallization from ethanol to yield colorless, needle shaped crystals of 2-hydroxy-3-methyl quinoxaline. Yield $80 \%$, m.p. $246{ }^{\circ}$ C. (Lit. m.p. $\left.245^{\circ} \mathrm{C}\right)^{14}$. IR (KBr) $3008 \mathrm{~cm}^{-1}$ for $(\mathrm{N}-\mathrm{H}$ stretching vibration of $2^{\circ}$ amide), $2968 \mathrm{~cm}^{-1}$ for (C-H stretching vibration of methyl group), $1665 \mathrm{~cm}^{-1}$ for $(\mathrm{C}=\mathrm{O}$ stretching vibration of amide) and $1610 \mathrm{~cm}^{-1}$ for $(\mathrm{C}=\mathrm{C})$ multiple bond stretching vibration of aromatic nucleus).

\section{Synthesis of 2-chloro 3-methylquinoxaline (3)}

2-Hydroxy-3-methyl quinoxaline $(16.0 \mathrm{~g}, 0.10 \mathrm{M})$ in $60 \mathrm{~mL}$ of $\mathrm{POCl}_{3}$ was refluxed for $90 \mathrm{~min}$. Then excess of $\mathrm{POCl}_{3}$ was distilled off and the residue was cooled to room temperature and added to crushed ice taken in a $1 \mathrm{~L}$ beaker. The mixture was made alkaline by adding $2 \%$ $\mathrm{NaOH}$ solution to isolate the product. The crude product was recrystallized from petroleum ether $\left(40-60{ }^{\circ} \mathrm{C}\right)$, to yield the crystals of 2-chloro-3-methyl quinoxaline $(3)$. Yield : $60 \%$, m.p. $88{ }^{\circ} \mathrm{C}$ (Lit. m.p. $\left.86-87{ }^{\circ} \mathrm{C}\right)^{15}$. IR $(\mathrm{KBr})$ data clearly showed the disappearance of $\mathrm{C}=\mathrm{O}$ stretching vibration of amide and appearance of $\mathrm{C}-\mathrm{Cl}$ stretching vibration of aryl halide at $1038.52 \mathrm{~cm}^{-1}$.

\section{Synthesis of 3-methylquinoxalin-2-thiosodium (4)}

A mixture of 2-chloro3-methylquinoxaline, $(0.9 \mathrm{~g}, 0.005 \mathrm{M})$ and sodium sulphide, $(0.8 \mathrm{~g}$, $0.005 \mathrm{M}$ ) in $10 \mathrm{~mL}$ of DMF was refluxed for $1.5 \mathrm{~h}$. The completion of reaction was indicated by a change in color of reaction mixture from dirty green to complete yellow color. This compound was prepared separately for each synthesis to follow.

\section{General method of synthesis of 2-chloro-N-(substituted phenyl)-acetamides}

Substituted anilines $(0.01 \mathrm{M})$ were dissolved in $10 \mathrm{~mL}$ of glacial acetic acid in a clean dry conical flask. Then chloroacetylchloride $(0.015 \mathrm{M})$ was added drop wise and the mixture was warmed on a water bath for 15-30 min with occasional swirling. Saturated solution of anhydrous sodium acetate was added to the warm solution to yield the precipitate on cooling in an ice bath. The product was filtered, washed well with water and purified by recrystallization from ethanol. The purity of compounds was validated by monitoring TLC. $N$-(benzo[d]thiazol-2-yl)-2-chloroacetamide was synthesized separately. A mixture of equimolar amounts of 2-aminobenzothiazole $(0.1 \mathrm{~mole})$ and chloroacetyl chloride $(0.1 \mathrm{~mole})$ in $30 \mathrm{~mL}$ chloroform with anhydrous $\mathrm{K}_{2} \mathrm{CO}_{3}(0.1$ mole) were refluxed for $14 \mathrm{~h}$. After completion of the reaction (monitored by TLC), excess of solvent was distilled off . The residue was stirred with water $(50 \mathrm{~mL})$ and treated with $5 \% \mathrm{NaHCO}_{3}(30 \mathrm{~mL})$ solution. The crude product was filtered washed with water to remove the alkali and recrystallized from methanol to yield the pale yellow product.

\section{Synthesis of 2-(2-methylquinoxalin-3-ylthio)-N-substituted phenyl)acetamides (5a-k)}

3-Methylquinoxalin-2-thiosodium was prepared as described earlier and then equimolar quantities of pure 2-chloro- $N$-(substituted phenyl)acetamide were added to the reaction vessel containing DMF and refluxed further for 6-9 $\mathrm{h}$. The reaction mixture was cooled to room temperature and added to ice water in a beaker with stirring. The crude product that separated was filtered, washed well with water, decolorized with activated charcoal and purified by recrystallization from ethanol. 


\section{2-(Benzylthio)-3-methyl quinoxaline $(\mathbf{5 l})$}

Benzyl chloride $(0.6 \mathrm{~mL}, 0.005 \mathrm{M})$ was added to reaction vessel containing 3-methylquinoxalin-2-thiosodium in DMF and refluxed for $2 \mathrm{~h}$. The mixture was cooled to room temperature and poured in to ice water in a beaker with stirring to yield the product, which was filtered, washed with water and recrystallized from ethanol to yield crystals of 2(benzylthio)-3-methylquinoxaline. The purity of compound was validated by m.p. determination and TLC technique. Physical data of compounds (5a-1) and structures are shown in the Table 2.

\section{Spectral data of the synthesized compounds (5a-5l)}

2-(2-Methylquinoxalin-3-ylthio)- $N$-(2-chlorophenyl)acetamide (5a)

IR (KBr cm$\left.{ }^{-1}\right)$ : $3280(\mathrm{~N}-\mathrm{H}), 3040(\mathrm{C}-\mathrm{H}), 2960\left(-\mathrm{CH}_{2^{-}}\right) 1650(\mathrm{C}=\mathrm{O}), 1600(\mathrm{C}=\mathrm{N}), 1440$ and $1250\left(-\mathrm{C}-\mathrm{S}-\mathrm{CH}_{2}\right), 1050(\mathrm{C}-\mathrm{Cl})$ aryl chloride and $640\left(\mathrm{CH}_{2}-\mathrm{S}\right) .{ }^{1} \mathrm{H}$ NMR $\left(\mathrm{CDCl}_{3}\right)$ : $\delta 2.745\left(\mathrm{~s}, 3 \mathrm{H}, \mathrm{CH}_{3}\right) \delta 4.224\left(\mathrm{~s}, 2 \mathrm{H}, \mathrm{CH}_{2}\right), \delta 6.987-8.345(\mathrm{~m}, 8 \mathrm{H}, \mathrm{Ar}-\mathrm{H})$ and at $\delta 9.166$ (s, 1H,N-H).

\section{2-(2-Methylquinoxalin-3-ylthio)-N-(3-chlorophenyl)acetamide (5b)}

IR $\left(\mathrm{KBr} \mathrm{cm}^{-1}\right): 3260(\mathrm{~N}-\mathrm{H}), 3040(\mathrm{C}-\mathrm{H}), 2880\left(-\mathrm{CH}_{2}-\right), 1660(\mathrm{C}=\mathrm{O}), 1600(\mathrm{C}=\mathrm{N}), 1420$ and $1250\left(-\mathrm{C}-\mathrm{S}-\mathrm{CH}_{2}\right), 1050(\mathrm{C}-\mathrm{Cl})$ aryl chloride and $680\left(\mathrm{CH}_{2}-\mathrm{S}\right) .{ }^{1} \mathrm{H}$ NMR $\left(\mathrm{CDCl}_{3}\right): \delta 2.839$ (s, 3H, CH3), $\delta 4.065\left(\mathrm{~s}, 2 \mathrm{H}, \mathrm{CH}_{2}\right), \delta 7.218--8.024(\mathrm{~m}, 8 \mathrm{H}, \mathrm{Ar}-\mathrm{H})$ and $\delta 8.495(\mathrm{~s}, 1 \mathrm{H}, \mathrm{N}-\mathrm{H})$.

\section{2-(2-Methylquinoxalin-3-ylthio)-N-(4-chlorophenyl)acetamide (5c)}

IR $\left(\mathrm{KBr} \mathrm{cm}^{-1}\right): 3250(\mathrm{~N}-\mathrm{H}), 3040(\mathrm{C}-\mathrm{H}), 2890\left(-\mathrm{CH}_{2}-\right), 1650(\mathrm{C}=\mathrm{O}), 1595(\mathrm{C}=\mathrm{N}), 1440$ and $1250\left(-\mathrm{C}-\mathrm{S}-\mathrm{CH}_{2}\right), 1050(\mathrm{C}-\mathrm{Cl})$ aryl chloride and $660\left(\mathrm{CH}_{2}-\mathrm{S}\right) .{ }^{1} \mathrm{H}$ NMR $\left(\mathrm{CDCl}_{3}\right)$ : $\delta 2.737\left(\mathrm{~s}, 3 \mathrm{H}, \mathrm{CH}_{3}\right), \delta 4.070\left(\mathrm{~s}, 2 \mathrm{H}, \mathrm{CH}_{2}\right), \delta 7.188--8.052(\mathrm{~m}, 8 \mathrm{H}, \mathrm{Ar}-\mathrm{H})$ and $\delta 9.748$ ( $\mathrm{s}, 1 \mathrm{H}, \mathrm{N}-\mathrm{H})$.

\section{2-(2-Methylquinoxalin-3-ylthio)-N-(4-bromophenyl)acetamide (5d)}

IR $\left(\mathrm{KBr} \mathrm{cm}^{-1}\right): 3280(\mathrm{~N}-\mathrm{H}), 3040(\mathrm{C}-\mathrm{H}), 2890\left(-\mathrm{CH}_{2}-\right), 1650(\mathrm{C}=\mathrm{O}), 1600(\mathrm{C}=\mathrm{N}), 1440$ and $1250\left(-\mathrm{C}-\mathrm{S}-\mathrm{CH}_{2}\right), 1045(\mathrm{C}-\mathrm{Br})$ aryl bromide and $680\left(\mathrm{CH}_{2}-\mathrm{S}\right) .{ }^{1} \mathrm{H}$ NMR $\left(\mathrm{CDCl}_{3}\right): \delta 2.736$ $\left(\mathrm{s}, 3 \mathrm{H}, \mathrm{CH}_{3}\right), \delta 4.067\left(\mathrm{~s}, 2 \mathrm{H}, \mathrm{CH}_{2}\right), \delta$ 7.257-8.056 (m,8H, Ar-H) and $\delta 9.756(\mathrm{~s}, 1 \mathrm{H}, \mathrm{N}-\mathrm{H})$.

\section{2-(2-Methylquinoxalin-3-ylthio)- $N$-p-tolyl acetamide (5e)}

IR $\left(\mathrm{KBr} \mathrm{cm}^{-1}\right): 3290(\mathrm{~N}-\mathrm{H}), 3040(\mathrm{C}-\mathrm{H}), 2890\left(-\mathrm{CH}_{2}-\right), 1650(\mathrm{C}=\mathrm{O}), 1610(\mathrm{C}=\mathrm{N}), 1400$ and $1250\left(-\mathrm{C}-\mathrm{S}-\mathrm{CH}_{2}\right)$ and $680\left(\mathrm{CH}_{2}-\mathrm{S}\right) .{ }^{1} \mathrm{H}$ NMR $\left(\mathrm{CDCl}_{3}\right): \delta 2.263$ and $\delta 2.319\left(\mathrm{~d}, 6 \mathrm{H}, 2 \mathrm{CH}_{3}\right)$, $\delta 3.431\left(\mathrm{~s}, 2 \mathrm{H}, \mathrm{CH}_{2}\right), \delta$ 6.694-7.691 $(\mathrm{m}, 8 \mathrm{H}, \mathrm{Ar}-\mathrm{H})$ and $\delta 8.400(\mathrm{~s}, 1 \mathrm{H}, \mathrm{N}-\mathrm{H})$.

\section{2-(2-Methylquinoxalin-3-ylthio)-N-(4-methoxyphenyl)acetamide (5f)}

IR $\left(\mathrm{KBr} \mathrm{cm}^{-1}\right): 3270(\mathrm{~N}-\mathrm{H}), 3040(\mathrm{C}-\mathrm{H}), 2840\left(-\mathrm{CH}_{2}-\right), 1650(\mathrm{C}=\mathrm{O}), 1600(\mathrm{C}=\mathrm{N}), 1400$ and $1250\left(-\mathrm{C}-\mathrm{S}-\mathrm{CH}_{2}\right), 1250 ; 1035(\mathrm{C}-\mathrm{O})$ and $640\left(\mathrm{CH}_{2}-\mathrm{S}\right) .{ }^{1} \mathrm{H} \mathrm{NMR}\left(\mathrm{CDCl}_{3}\right): \delta 2.738$ $\left(\mathrm{s}, 3 \mathrm{H}, \mathrm{CH}_{3}\right), \delta 3.743\left(\mathrm{~s}, 3 \mathrm{H}, \mathrm{OCH}_{3}\right), \delta 4.073\left(\mathrm{~s}, 2 \mathrm{H}, \mathrm{CH}_{2}\right), \delta 6.774-8.042(\mathrm{~m}, 8 \mathrm{H}, \mathrm{Ar}-\mathrm{H})$ and $\delta$ $9.487(\mathrm{~s}, 1 \mathrm{H}, \mathrm{N}-\mathrm{H})$.

\section{2-(2-Methylquinoxalin-3-ylthio)- $\mathrm{N}$-(3-chloro-4-fluorophenyl)acetamide (5g)}

IR $\left(\mathrm{KBr} \mathrm{cm}^{-1}\right): 3280(\mathrm{~N}-\mathrm{H}), 3020(\mathrm{C}-\mathrm{H}), 2880\left(-\mathrm{CH}_{2}-\right), 1670(\mathrm{C}=\mathrm{O}), 1600(\mathrm{C}=\mathrm{N}), 1440$ and $1250\left(-\mathrm{C}-\mathrm{S}-\mathrm{CH}_{2}\right), 1115(\mathrm{C}-\mathrm{F})$ aryl chloride $1050(\mathrm{C}-\mathrm{Cl})$ aryl chloride and $680\left(\mathrm{CH}_{2}-\mathrm{S}\right) .{ }^{1} \mathrm{H}$ NMR $\left(\mathrm{CDCl}_{3}\right): \delta 2.737\left(\mathrm{~s}, 3 \mathrm{H}, \mathrm{CH}_{3}\right) \delta 4.062\left(\mathrm{~s}, 2 \mathrm{H}, \mathrm{CH}_{2}\right), \delta 6.964-8.058(\mathrm{~m}, 7 \mathrm{H}, \mathrm{Ar}-\mathrm{H})$ and $\delta$ $9.776(\mathrm{~s}, 1 \mathrm{H}, \mathrm{N}-\mathrm{H})$. 


\section{2-(2-Methylquinoxalin-3-ylthio)- $N$-(2, 3-dimethylphenyl)acetamide (5h)}

IR $\left(\mathrm{KBr} \mathrm{cm}^{-1}\right)$ : $3280(\mathrm{~N}-\mathrm{H}), 3000(\mathrm{C}-\mathrm{H}), 2900\left(-\mathrm{CH}_{2}-\right), 1650(\mathrm{C}=\mathrm{O}), 1600(\mathrm{C}=\mathrm{N}), 1440$ and $1250\left(-\mathrm{C}-\mathrm{S}-\mathrm{CH}_{2}\right)$, and $680\left(\mathrm{CH}_{2}-\mathrm{S}\right) .{ }^{1} \mathrm{H}$ NMR $\left(\mathrm{CDCl}_{3}\right): \delta 2.755\left(\mathrm{~s}, 3 \mathrm{H}, \mathrm{CH}_{3}\right), \delta 1.905$ and $\delta 2.198\left(\mathrm{~d}, 6 \mathrm{H}, 2 \mathrm{CH}_{3}\right), \delta 4.179\left(\mathrm{~s}, 2 \mathrm{H}, \mathrm{CH}_{2}\right), \delta 6.947-8.005(\mathrm{~m}, 7 \mathrm{H}, \mathrm{Ar}-\mathrm{H})$ and $\delta 8.768(\mathrm{~s}, 1 \mathrm{H}$, N-H). MS: $m / z 338\left(\mathbf{M}^{+}+1\right)$

Methyl-2-(2-(2-methylquinoxalin-3-ylthio) acetamide)benzoate (5i)

IR $\left(\mathrm{KBr} \mathrm{cm}^{-1}\right): 3280(\mathrm{~N}-\mathrm{H}), 2960(\mathrm{C}-\mathrm{H}), 2900\left(-\mathrm{CH}_{2}-\right), 1680(\mathrm{C}=\mathrm{O}), 1600(\mathrm{C}=\mathrm{N}), 1440$ and 1250 $\left(-\mathrm{C}-\mathrm{S}-\mathrm{CH}_{2}\right), 1270 ; 1115(\mathrm{C}-\mathrm{O})$ and $700\left(\mathrm{CH}_{2}-\mathrm{S}\right) .{ }^{1} \mathrm{H}$ NMR $\left(\mathrm{CDCl}_{3}\right): \delta 2.794\left(\mathrm{~s}, 3 \mathrm{H}_{2}, \mathrm{CH}_{3}\right), \delta 3.760$ $\left(\mathrm{s}, 3 \mathrm{H}, \mathrm{OCH}_{3}\right), \delta 4.278\left(\mathrm{~s}, 2 \mathrm{H}, \mathrm{CH}_{2}\right), \delta 7.026-8.690(\mathrm{~m}, 8 \mathrm{H}, \mathrm{Ar}-\mathrm{H})$ and $\delta 11.631(\mathrm{~s}, 1 \mathrm{H}, \mathrm{N}-\mathrm{H})$.

\section{2-(2-Methylquinoxalin-3-ylthio)- $N$-(benzo[d]thiazol-2-yl)acetamide (5j)}

IR (KBr cm$\left.{ }^{-1}\right): 3260(\mathrm{~N}-\mathrm{H}), 3040(\mathrm{C}-\mathrm{H}), 2900\left(-\mathrm{CH}_{2^{-}}\right), 1700(\mathrm{C}=\mathrm{O}), 1600(\mathrm{C}=\mathrm{N}), 1440$ and $1250\left(-\mathrm{C}-\mathrm{S}-\mathrm{CH}_{2}\right), 740$ (Benzothiazole ring) and $690\left(\mathrm{CH}_{2}-\mathrm{S}\right) .{ }^{1} \mathrm{H}$ NMR $\left(\mathrm{CDCl}_{3}\right): \delta 2.739$ $\left(\mathrm{s}, 3 \mathrm{H}, \mathrm{CH}_{3}\right), \delta 4.191\left(\mathrm{~s}, 2 \mathrm{H}, \mathrm{CH}_{2}\right), \delta$ 7.261-8.143 (m,8H, Ar-H) and $\delta 11.303(\mathrm{~s}, 1 \mathrm{H}, \mathrm{N}-\mathrm{H})$.

\section{2-(2-Methylquinoxalin-3-ylthio) $-\mathrm{N}$-cyclohexylacetamide (5k)}

IR $\left(\mathrm{KBr} \mathrm{cm}^{-1}\right): 3280(\mathrm{~N}-\mathrm{H}), 2960(\mathrm{C}-\mathrm{H}), 2900\left(-\mathrm{CH}_{2}-\right), 1640(\mathrm{C}=\mathrm{O}), 1550(\mathrm{C}=\mathrm{N}), 1440$ and 1250 $\left(-\mathrm{C}-\mathrm{S}-\mathrm{CH}_{2}\right)$, and $720\left(\mathrm{CH}_{2}-\mathrm{S}\right){ }^{1} \mathrm{H} \mathrm{NMR}\left(\mathrm{CDCl}_{3}\right): \delta 1.005-1.841\left(\mathrm{~m}, 10 \mathrm{H}, \mathrm{C}_{6} \mathrm{H}_{10}\right), \delta 2.838\left(\mathrm{~s}, 3 \mathrm{H}, \mathrm{CH}_{3}\right)$, $\delta 3.722-3.748(\mathrm{t}, 1 \mathrm{H}, \mathrm{CH}-), \delta 3.927\left(\mathrm{~s}, 2 \mathrm{H}, \mathrm{CH}_{2}\right) \delta 7.144-7.986(\mathrm{~m}, 4 \mathrm{H}, \mathrm{Ar}-\mathrm{H})$ and $\delta 8.011(\mathrm{~s}, 1 \mathrm{H}, \mathrm{N}-\mathrm{H})$.

\section{2-(Benzylthio)-3-methylquinoxaline (5l)}

IR $\left(\mathrm{KBr} \mathrm{cm}^{-1}\right)$ : $\left.2960(\mathrm{C}-\mathrm{H}),\right), 2900\left(-\mathrm{CH}_{2}-\right), 1600(\mathrm{C}=\mathrm{N}), 1440$ and $1250\left(-\mathrm{C}-\mathrm{S}-\mathrm{CH}_{2}\right)$ and 720 $\left(\mathrm{CH}_{2}-\mathrm{S}\right) .{ }^{1} \mathrm{H}$ NMR $\left(\mathrm{CDCl}_{3}\right): \delta 2.834(\mathrm{~s}, 3 \mathrm{H}, \mathrm{CH} 3), \delta 4.065(\mathrm{~s}, 2 \mathrm{H}, \mathrm{CH} 2)$ and $\delta 7.260-8.051$ (m, 9H, Ar-H).

\section{Antibacterial activity}

The antibacterial activity was assayed by agar plate disc diffusion method ${ }^{16}$ at the concentration of $50 \mu \mathrm{g}$ per disk. All the synthesized compounds were tested in vitro for their antibacterial activity against gram positive microorganisms such as Staphylococcus aureus (NCIM 2079), Bacillus subtilis (NCIM 2439) and gram negative Escherichia coli (NCIM 2831), Pseudomonas aerugenosa (NCIM 2863) strains. Each test compounds were dissolved in dimethyl sulphoxide (DMSO) to get a concentration of $10 \mathrm{mg} / \mathrm{mL}$. The disc $(6 \mathrm{~mm}$ in diameter) was impregnated with $5 \mu \mathrm{L}$ of each test solution to get $50 \mu \mathrm{g} / \mathrm{disc}$, air dried and placed on the agar medium, previously seeded with $0.2 \mathrm{~mL}$ of broth culture of each organism for $18 \mathrm{~h}$. The plates were incubated at $37{ }^{\circ} \mathrm{C}$ for $24 \mathrm{~h}$ and the inhibition zones were measured in $\mathrm{mm}$. Discs impregnated with DMSO were used as a control and ciprofloxacin discs as antibacterial reference standard.

\section{Antifungal activity}

The antifungal activity ${ }^{17}$ was assayed by sabouraud dextrose agar media plate disc diffusion method at the concentration of $50 \mu \mathrm{g}$ per disk. All the synthesized compounds were tested in vitro for their antifungal activity against microorganisms such as Asperagellus niger (NCIM 618) and Candida albicans (NCIM 3557). Each test compound was dissolved in dimethyl sulphoxide (DMSO) to get a concentration of $10 \mathrm{mg} / \mathrm{mL}$. The disc $(6 \mathrm{~mm}$ in diameter) was impregnated with $5 \mu \mathrm{L}$ of each test solution to get $50 \mu \mathrm{g} / \mathrm{disc}$; air dried and placed on the sabouraud dextrose agar media, previously seeded with $0.2 \mathrm{~mL}$ of broth culture of each organism for $18 \mathrm{~h}$. The plates were incubated at $22{ }^{\circ} \mathrm{C}$ for $48 \mathrm{~h}$ and the inhibition zones were measured in $\mathrm{mm}$.Discs impregnated with DMSO were used as a control and fluconazole discs as antifungal reference standard. 


\section{Results and Discussion}

The IR spectra of compounds (5a-k) showed bands at $3280 \mathrm{~cm}^{-1}(\mathrm{~N}-\mathrm{H})$ stretching vibration for secondary amides, at $2920 \mathrm{~cm}^{-1}\left(-\mathrm{CH}_{2}\right)$ - stretching vibration, at $1650-1700 \mathrm{~cm}^{-1}(\mathrm{C}=\mathrm{O})$ stretching vibration for amides, at $1440-1250 \mathrm{~cm}^{-1}\left(-\mathrm{C}-\mathrm{S}_{-}-\mathrm{CH}_{2}-\right)$ stretching vibration and at $640 \mathrm{~cm}^{-1}$ (-C-S-) stretching vibration. The ${ }^{1} \mathrm{H}$ NMR spectra also confirmed this synthesis by showing $\delta$ values for various hydrogens. The ${ }^{1} \mathrm{H}$ NMR spectra revealed a singlet at $\delta 2.838$ for $\mathrm{CH}_{3}$ of quinoxaline ring, a singlet at $\delta 3.900-4.300$ for(- $\left.-\mathrm{S}^{-} \mathrm{CH}_{2}-\right)$, a singlet at $\delta 8.000-9.700$ for secondary $(\mathrm{N}-\mathrm{H})$ and multiplets at $\delta$ 6.900-8.000 for aromatic hydrogens. The attachment of various substituent groups in the synthesized compounds were also validated by their respective IR and ${ }^{1} \mathrm{H}$ NMR spectra. The mass spectrum of compound (5h) has further validated the structure of this compound.

\section{Antibacterial activity}

The antibacterial activity was determined by the disc diffusion method at the concentration of $50 \mu \mathrm{g}$ per disk. All the synthesized compounds were tested in vitro for their antibacterial activity against gram positive microorganisms such as Staphylococcus aureus (NCIM 2079), Bacillus subtilis (NCIM 2439), Escherichia coli (NCIM 2831), Pseudomonas aerugenosa(NCIM 2863) (gram negative), using ciprofloxacin as standard antibacterial. The results of activity, presented in the Table 3 suggested that the compounds $\mathbf{5 a}, \mathbf{5 c}, \mathbf{5 d}, \mathbf{5 h}, \mathbf{5 i}, \mathbf{5 j}$, $\mathbf{5 k}$ and $\mathbf{5 l}$ were highly active where as compounds $\mathbf{5 b}, \mathbf{5 e}, \mathbf{5 f}$ and $\mathbf{5 g}$ were moderately active against microorganism $S$. aureus. The compound $\mathbf{5 b}$ only was found highly active and rest of the compounds was found moderately active against $B$. subtilis. The compounds $\mathbf{5 j}$ and $\mathbf{5 k}$ were found highly active and rest moderately active against microorganism E.coli. The activity of the compounds $\mathbf{5 b}, \mathbf{5 c}, \mathbf{5 d}$ and $\mathbf{5 i}$ were found most active, (comparable to standard antibacterial ciprofloxacin), $\mathbf{5} \mathbf{j}$ moderately active whereas compounds $\mathbf{5 a}, \mathbf{5 e}, \mathbf{5 f}, \mathbf{5 h}$ and $\mathbf{5 l}$ were found inactive against microorganism P.aerugenosa (Table 3).

Table 3. Results of antimicrobial activity

\begin{tabular}{|c|c|c|c|c|c|c|}
\hline \multirow[t]{2}{*}{ Compounds } & \multicolumn{6}{|c|}{ Zone of Inhibition } \\
\hline & S. aureus & B. subtilis & E.coli. & P.aerugenosa & A.niger & C.albican \\
\hline $5 a$. & +++ & ++ & ++ & - & ++ & - \\
\hline $5 b$. & ++ & +++ & ++ & +++ & ++ & - \\
\hline 5c. & +++ & ++ & ++ & +++ & ++ & - \\
\hline $5 d$. & +++ & ++ & ++ & +++ & ++ & - \\
\hline $5 e$. & ++ & ++ & ++ & - & ++ & ++ \\
\hline 5f. & ++ & ++ & ++ & - & ++ & ++ \\
\hline $5 g$. & ++ & ++ & ++ & +++ & ++ & +++ \\
\hline $5 \mathrm{~h}$. & +++ & ++ & ++ & - & ++ & ++ \\
\hline $5 i$. & +++ & ++ & ++ & +++ & - & - \\
\hline $5 \mathbf{j}$. & +++ & ++ & +++ & ++ & +++ & +++ \\
\hline $5 \mathrm{k}$. & +++ & ++ & +++ & ++ & ++ & +++ \\
\hline 51. & +++ & ++ & ++ & - & ++ & ++ \\
\hline Ciprofloxacin & +++ & +++ & & & & \\
\hline Fluconazole & & & & & +++ & +++ \\
\hline
\end{tabular}

'- Inactive (inhibition zone < $6 \mathrm{~mm}$ ); slightly active = '+' (inhibition zone 7-9 mm); moderately active = '++' (inhibition zone 10-13 mm); highly active = ‘+++' (inhibition zone $>14 \mathrm{~mm})$. 


\section{Antifungal activity}

The antibacterial activity was determined by the disc diffusion method at the concentration of 50 $\mu \mathrm{g}$ per disk. All the synthesized compounds were tested in vitro for their antifungal activity against microorganisms such as Asperagellus niger and Candida albicans, using fluconazole as standard antifungal. The compound $\mathbf{5 j}$ was highly active against both microorganisms Asperagellus niger (NCIM 618) and Candida albicans (NCIM 3557). Compounds 5g and 5k were highly active where as compounds $5 \mathbf{a}, \mathbf{5 b}, \mathbf{5 c}, \mathbf{5 d}$ and $\mathbf{5 i}$ were inactive against Candida albicans while rest of the compounds showed moderate activity against Asperagellus niger.

\section{Conclusion}

A series of the compounds (5a-5l) were synthesized and tested for antimicrobial activity, the compound $\mathbf{5 b}, \mathbf{5 c}, \mathbf{5 d}$ and $\mathbf{5 i}$ were found most active (comparable to standard antibacterial Ciprofloxacin) against P.aerugenosa. The compound 5j was highly active against both microorganisms Asperagellus niger and Candida albicans when compared to Fluconazole as standard antifungal agent.

\section{Acknowledgment}

The authors are thankful to Director, College of Pharmacy and Managing Director, I.F.T.M. Moradabad for providing research facilities. We extend our thanks to Director, National Collection of Industrial Microorganisms, National Chemical Laboratory, Pune for providing microbial strains.

\section{References}

1. Badran M M, Abonzid K A and Hussein M H, Arch Pharm Res., 2003, 26(2), 107-113.

2. Griffith R K, Chittur S V and Chen Y C, Med Chem Res., 1992, 2, 467-473.

3. E-lGendy A A, El-Meligie S, El-Ansry A and Ahmedy A M, Arch Pharm Res., 1995, 18, 44-47.

4. Reddy-Sastry C V, Shrinivas-Rao K, Krishanan V S H, Rastogi K, Jain M L and Narayanan G K A S S, Indian J Chem., 1990; 29B:396-403.

5. El-Hawash S A, Habib N S and Franki N H, Pharmazie, 1999, 54(11),808-815.

6. Westphal G, Wasiki H, Zielinski U ,Weberr F G, Tonew $\mathrm{M}$ and Tonew $\mathrm{E}$ and Potentielle Wiostatica, Pharmazie, 1977, 32, 570-571.

7. Monge A, Martinez-Crespo F J, Cerai A L, Palop J A, Narro S, Senador V, Marin A, Sainz Y, Gonzalez M, Hamilton E and Barker A J, J Med Chem., 1995, 38, 4488-4495.

8. Michael J W, Taibi Ben-Hadda, Ann T K, Ramdani A, Touzani R, Elkadiri S, Hakkou A, Boukka M and Elli T, Molecule, 2002, 7, 641.

9. Rangisetty J B, Gupta CNVHB, Prasad A L, Srinavas P, Sridhar N, Parimoo P and Veeranjaneyulu A, J Pharm Pharmacol., 2001, 53(10), 1409-1413.

10. Wagle S, Adhikari A V and Kumari N S, Indian J Chem., 2008, 47B, 439-448.

11. Silvia Schenone, Olga Bruno, Angelo Ranise, Francesco Bondavalli, Walter Filippelli, Francesca Rossi and Giuseppe Falcone, IIFarmaco., 1998, 53(8-9), 590-593.

12. Gulerman N N, Doan H N, Rollas S, Johnsson C and Colik C, II Farmaco., 1998, 53(8-9), 590-593.

13. Singh D C P, Deivedi S K, Hashim S R and Singhal R G, Pharmaceuticals, 2010, 3, 2416-2425.

14. Leese C L and Rydon H N, J Chem Soc., 1956, 303.

15. Platt and Sharp, J Chem Soc., 1948, 2129.

16. Collin C H, Microbiological Methods, Butter Wrths, London, 1964, 92.

17. Gravestock M B and Ryley J F, Antifungal Chemotherapy Annual Reports in Medicinal Chem., 1984, 19,127. 


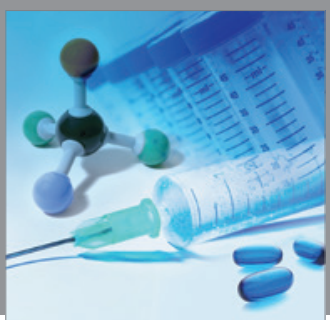

International Journal of

Medicinal Chemistry

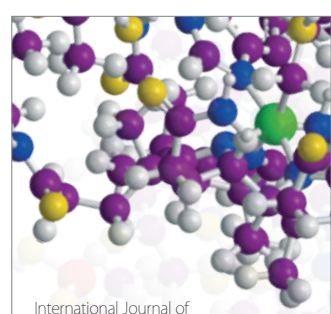

Carbohydrate Chemistry

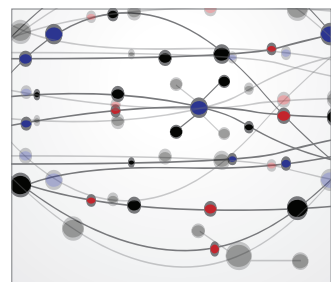

The Scientific World Journal
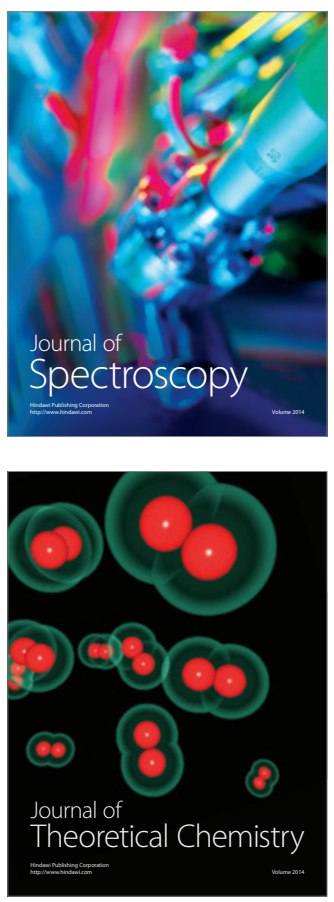
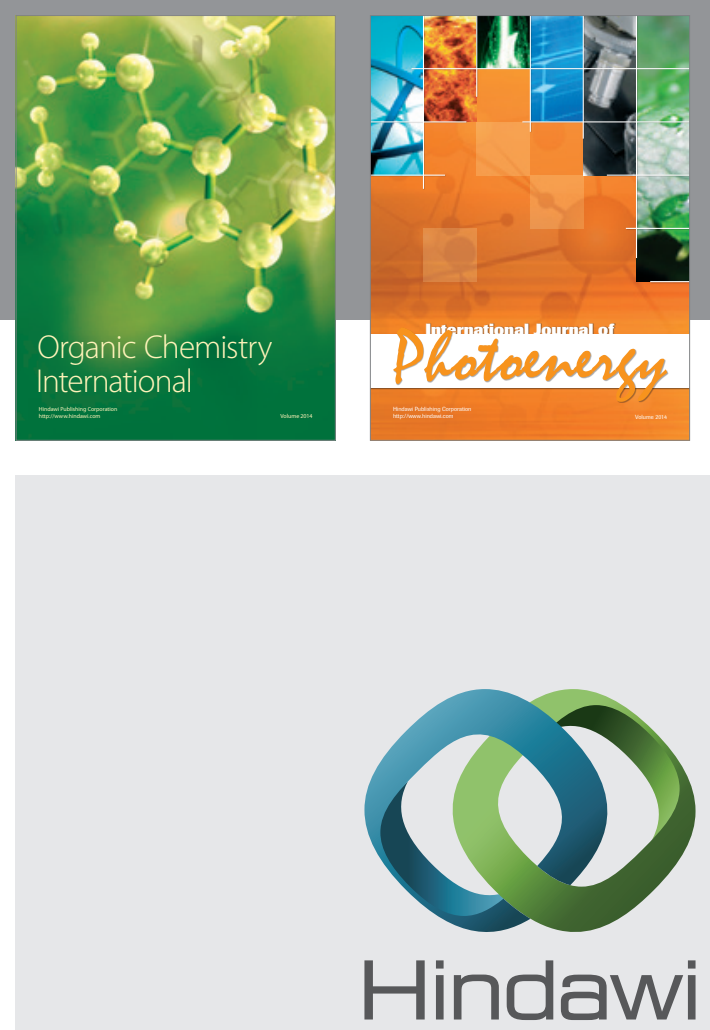

Submit your manuscripts at

http://www.hindawi.com
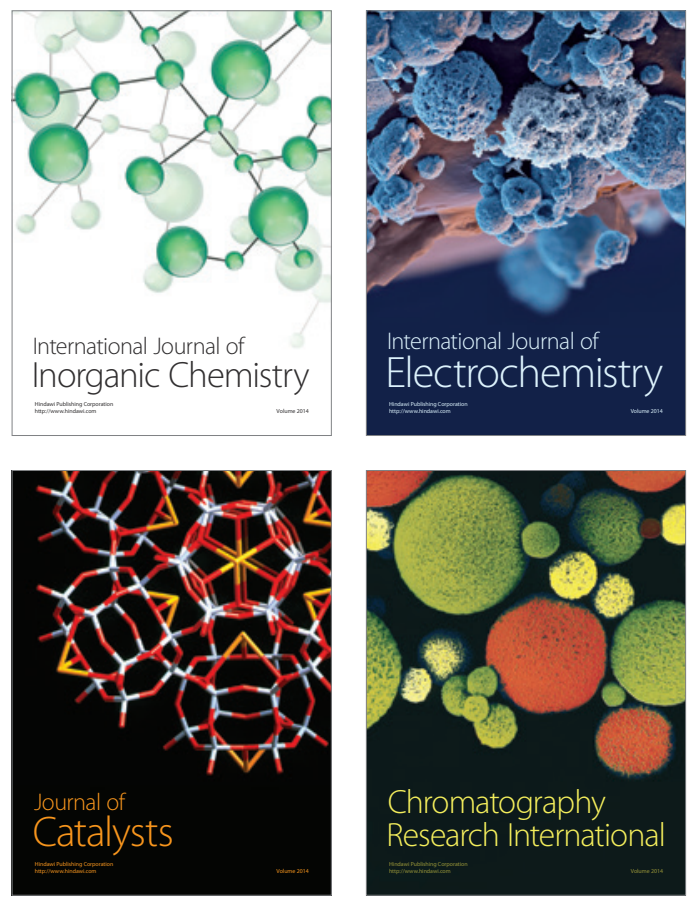
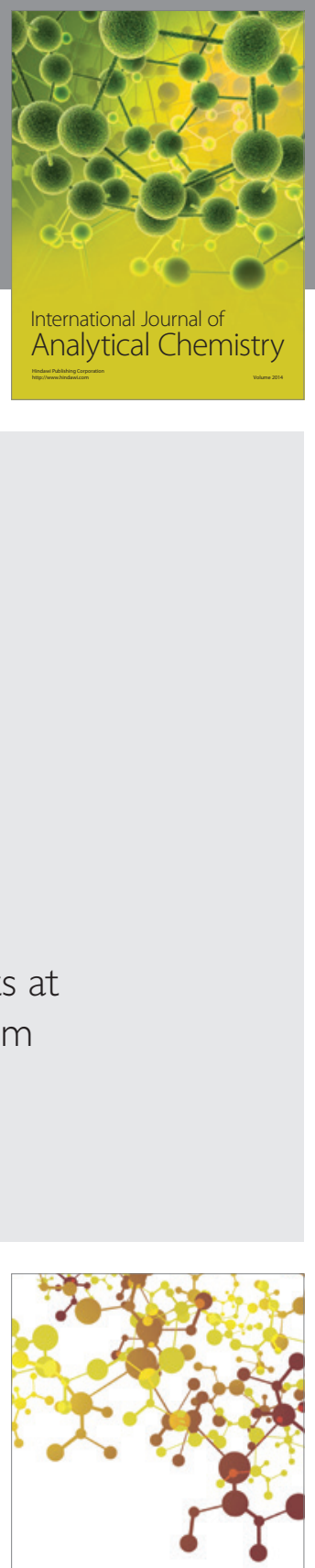

Journal of

Applied Chemistry
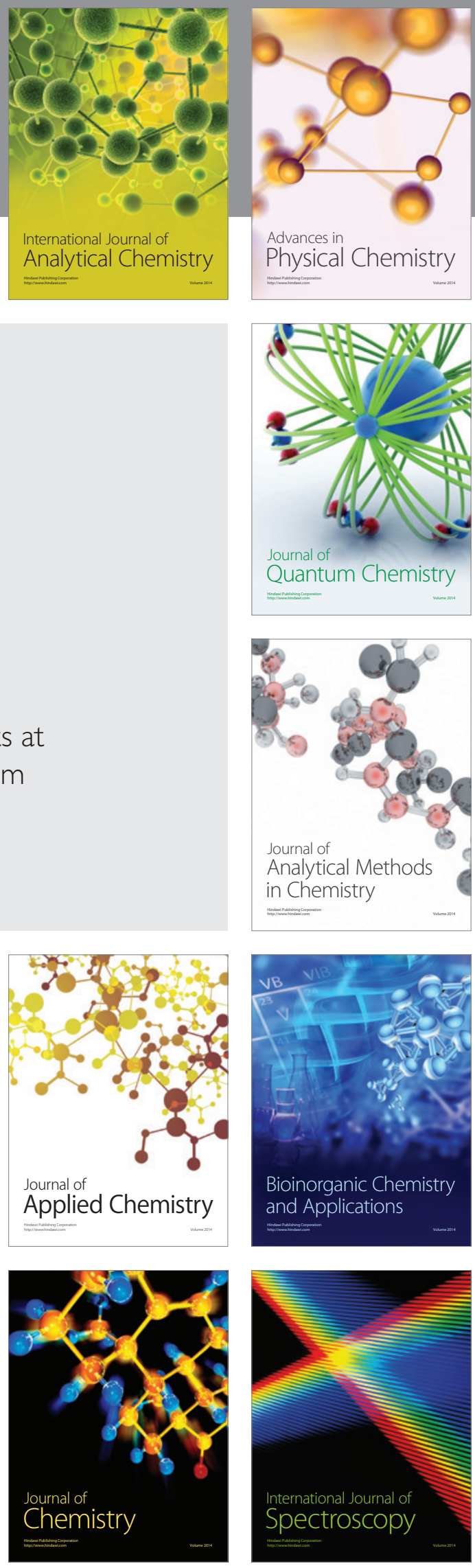